\title{
Analisis Pertumbuhan Laba dalam Rasio Keuangan pada PT Semen Indonesia Tbk
}

\section{Analysis of Income Growth in Financial Ratios in PT Semen Indonesia Tbk}

\author{
Vina Arnita1), Aulia'1), Eky Ermal Muttaqin ${ }^{2)}$ \& Suryani1) \\ 1) Program Studi Akuntansi, Fakultas Sosial Sains , Universitas Pembangunan Panca Budi, \\ Indonesia \\ 2) Program Studi Akuntansi, Fakultas Ekonomi dan Bisnis , Universitas Medan Area, Indonesia
}

\begin{abstract}
Abstrak
Tujuan penelitian ini adalah untuk mengetahui pengaruh variabel Current Ratio, Total Assets Turnover, Gross Profit Margin, dan Return on Equity dalam memprediksi pertumbuhan laba. Data yang digunakan adalah laporan keuangan yaitu laporan laba rugi komprehensif dan laporan posisi keuangan 5 perusahaan industri dasar dan kima yang terdaftar di Bursa Efek Indonesia tahun 2011 - 2017. Untuk menguji hipotesis digunakan analisis regresi, ujiT, uji-F, dan uji asumsi klasik. Hasil uji statistik menunjukkan bahwa Total Assets Turnover, Gross Profit Margin, dan Return on Equity berpengaruh signifikan dalam memprediksi pertumbuhan laba pada perusahaan industri dasar dan kimia yang terdaftar di Bursa Efek Indonesia sedangkan Current Ratio tidak berpengaruh signifikan dalam memprediksi pertumbuhan laba pada perusahaan industri dasar dan kimia yang terdaftar di Bursa Efek Indonesia Kata kunci: Current Ratio, Total Assets Turnover, Gross Profit Margin, Return on Equity, dan Pertumbuhan Laba.
\end{abstract}

\begin{abstract}
This research was aimed to know the effects of variable Current Ratio, Total Assets Turnover, Gross Profit Margin, dan Return on Equity could be used to predict profit growth. The data used were the financial statements. Those were the Statement of Comprehensif Income and Statement of Financial Posisition of 5 basic industry and chemicals companies listed in Indonesian Stock Exchange from 2011 - 2017. To test hypothesis could be used regression analysis, T-test, Ftest, and classical assumption test. The result of research showed that Total Assets Turnover, Gross Profit Margin, dan Return on Equity were significant effect to predict profit growth at basic industry and chemicals companies listed in Indonesian Stock Exchange while Current Ratio weren't significant effect to predict profit growth at basic industry and chemicals companies listed in Indonesian Stock Exchange.

Keywords: Current Ratio, Total Assets Turnover, Gross Profit Margin, Return on Equity, Profit Growth.
\end{abstract}

How to Cite: Arnita, V. Aulia. Muttaqin, E.E \& Suryani. (2021). Analisis Pertumbuhan Laba dalam Rasio Keuangan pada PT Semen Indonesia Tbk. Economics, Business and Management Science Journal, 1(1): 15 ,

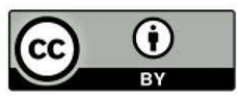




\section{PENDAHULUAN}

Perkembangan ekonomi yang semakin pesat saat ini menyebabkan persaingan bisnis yang semakin ketat. Agar perusahaan dapat bertahan dalam kondisi ini, maka perusahaan harus dapat mengendalikan seluruh kegiatan operasi dan kondisi keuangannya secara efektif, efisien, dan ekonomis. Kondisi keuangan disajikan kepada para pihak yang memiliki kepentingan terhadap perusahaan.

Menurut Rudianto (2012), "Perusahaan manufaktur adalah perusahaan yang membeli bahan baku, mengolahnya hingga menjadi produk jadi yang siap dipakai, dan menjual kepada konsumen yang membutuhkannya. Fungsi utama perusahaan manufaktur adalah sebagai jembatan antara perusahaan penghasil bahan mentah dan konsumen yang membutuhkan barang yang memiliki nilai tambah yang lebih tinggi dari bahan mentah tersebut. Berbeda dengan perusahaan dagang yang membeli dan menjualnya dalam bentuk yang sama, perusahaan manufaktur harus mengolah terlebih dahulu bahan baku atau bahan mentah yang dibelinya sebelum menjualnya kepada masyarakat."

Kondisi keuangan suatu perusahaan dapat dilihat dari laporan keuangan yang diterbitkan secara berkala seperti laporan keuangan tengah tahunan dan laporan keuangan akhir tahun. Laporan keuangan merupakan salah satu sumber informasi penting bagi para pemakai laporan keuangan untuk mengambil keputusan ekonomi. Laporan keuangan akan menjadi lebih bermanfaat untuk pengambilan keputusan, apabila dengan laporan keuangan tersebut dapat diprediksi apa yang akan terjadi di masa yang akan datang.

Dengan mengelolah lebih lanjut laporan keuangan melalui proses pembandingan, evaluasi, dan analisis trend akan diperoleh prediksi apa yang akan terjadi di masa yang akan datang. Maraknya iklim investasi dan makin berkembangnya berbagai pembiayaan investasi, khususnya ditandai dengan berperannya pasar modal dan industri perbankan telah mendorong makin dibutuhkannya analisis keuangan. Dari sinilah pentingnya analisis terhadap suatu laporan keuangan (Arnita, \& Aulia, 2020; Arnita, 2019).

Menurut Subramanyam (2014), "Analisis laporan keuangan (financial statement analysis) adalah aplikasi dari alat dan teknik analitis untuk laporan keuangan bertujuan umum dan datadata yang berkaitan untuk menghasilkan estimasi dan kesimpulan yang bermanfaat dalam analisis bisnis. Analisis laporan keuangan mengurangi ketergantungan pada firasat, tebakan, dan intuisi dalam pengambilan keputusan, serta mengurangi ketidakpastian analisis bisnis."

Menurut Trihastuti (2008), "Seperti kita ketahui tujuan utama didirikannya suatu perusahaan adalah untuk memperoleh laba yang nantinya akan diperlukan untuk perkembangan dan kelangsungan hidup perusahaan. Laba yang diperoleh perusahaan juga seringkali dipakai sebagai ukuran untuk menilai berhasil tidaknya manajemen dalam mengelola perusahaan. Kemampuan perusahaan dalam memperoleh laba di masa yang akan datang merupakan salah satu indikasi kinerja dan prospek perusahaan. Dengan demikian perkiraan laba merupakan suatu informasi yang sangat menarik perhatian para investor. Bagi para investor, prospek perusahaan di masa yang akan datang lebih penting dibandingkan informasi yang bersifat historis. Berdasarkan hal tersebut keandalan informasi perkiraan laba suatu perusahaan yang akan datang sangat penting. Karena laba perusahaan diperlukan untuk kepentingan kelangsungan hidup perusahaan dan ketidakmampuan perusahaan dalam mendapat laba akan menyebabkan tersingkirnya perusahaan dalam dunia bisnis."

\section{METODE PENELITIAN}

Menurut penelitian Taruh (2011), "Gross Profit Margin berpengaruh signifikan dalam pertumbuhan laba. Gross Profit Margin merupakan rasio antara laba kotor (yaitu penjualan bersih dikurangi dengan harga pokok penjualan) terhadap penjualan bersih. GPM yang meningkat menunjukkan semakin besar tingkat kembalian keuntungan kotor yang diperoleh perusahaan terhadap penjualan bersihnya. Ini berarti semakin efisien biaya yang dikeluarkan perusahaan untuk menunjang kegiatan penjualan sehingga pendapatan yang diperoleh menjadi meningkat."

Pendekatan penelitian ini adalah penelitian asosiatif. Menurut Rusiadi (2013), "Penelitian asosiatif/kuantitatif merupakan penelitian yang bertujuan untuk mengetahui derajat hubungan dan pola/bentuk pengaruh antar dua variabel atau lebih, dimana dengan penelitian ini maka akan 
dibangun suatu teori yang berfungsi untuk menjelaskan, meramalkan dan mengontrol suatu gejala."

Menurut Sugiyono (2011), "Populasi adalah wilayah generalisasi yang terdiri atas obyek/subyek yang mempunyai kualitas dan karakteristik tertentu yang ditetapkan oleh peneliti untuk dipelajari dan kemudian ditarik kesimpulannya." Populasi yang digunakan dalam penelitian ini adalah 20 perusahaan industri dasar dan kimia yang terdaftar di Bursa Efek Indonesia.

Teknik pengumpulan data yang digunakan dalam penelitian ini adalah dokumentasi. Menurut Tanzeh (2011), "Dokumentasi yaitu mengumpulkan data dengan melihat atau mencatat suatu laporan yang sudah tersedia." Data yang digunakan adalah data sekunder dari laporan keuangan yang telah dipublikasikan di Bursa Efek Indonesia.

\section{HASIL DAN PEMBAHASAN}

Berdasarkan Anggaran Dasar Perusahaan, ruang lingkup kegiatan SMGR meliputi berbagai kegiatan industri. Saat ini kegiatan utama perusahaan adalah bergerak di industri semen. Hasil produksi perusahaan dan anak usaha dipasarkan di dalam dan luar negeri. Adapun hasil penelitian dari rasio -rasio perusahaan japfa comfeed adalah:

Tabel 1. Daftar Rasio - rasio

\begin{tabular}{|c|c|c|c|c|c|c|c|c|}
\hline \multirow{2}{*}{ Nama } & \multirow{2}{*}{$\begin{array}{l}\text { NAMA } \\
\text { PERUSAHAAN }\end{array}$} & \multicolumn{7}{|l|}{ Tahun } \\
\hline & & 2011 & 2012 & 2013 & 2014 & 2015 & 2016 & 2017 \\
\hline Current Ratio & SMRG & 264.65 & 170.59 & 188.24 & 220.90 & $159 \cdot 70$ & 127.25 & 156.78 \\
\hline Total asset turnover & SMRG & 83.30 & 73.74 & $79 \cdot 57$ & 78.60 & 70.63 & 59.09 & 56.80 \\
\hline Gross profit margin & SMRG & $45 \cdot 71$ & 47.44 & 44.67 & 42.98 & $39 \cdot 51$ & 37.71 & 28.62 \\
\hline Return On Equity & SMRG & 20.12 & 27.12 & 24.56 & 22.29 & 16.49 & 14.83 & 6.71 \\
\hline Pertumbuhan Laba & SMRG & 8.09 & 24.56 & 8.68 & 3.98 & -18.72 & 0.21 & -54.95 \\
\hline
\end{tabular}

Dalam table menunjukkan current ratio,total asset turnover,gross profit margin,return on equity dan pertumbuhan laba. Adapun current ratio dilihat dari tahun 2011 sampai dengan 2017 kenaikan mengalami fluktasi yaitu hanya ditahun 204 yang mengalami kenaikan dari tahun sebelumnya yaitu 220.90. Sedangkan total asset turnover mengalami penurunan setiap tahunnya dan diikuiti oleh gross profit margin mengalami penurunan setiap tahunnya. Dilihat dari return on Equity Perusahaan Semen Indonesia mengalami penurunan setiap tahun. Pertumbuhan laba ditahun 2012 mengalami kenaikan sebesar 24.56 sedangkan tahun berikutnya pertumbuhan laba mengalami penurunan.

Jika dilihat dari total asset turnover dari tahun 2011 sampai dengan tahun 2017 mengalami penurunan setiap tahunnya. Sedangkan gross profit margin juga mengalami penurunan setiap tahunnya dari tahun 2011 sampai dengan tahun 2017,begitu juga dengan return on equity mengalami penurunan pada tahun 2014 sampai 2015.Pertumbuhan laba juga mengalami minus ditahun 2011,2013,2014 dan 2017 mengalami penurunan. Pertumbuhan laba banyak dipengaruhi berbagai factor yaitu factor manajemen dengan tidak bekerja dengan maksimal sehingga laba perusahaan mengalami penurunan.

Berdasarkan hasil penelitian yang telah diuraikan secara spesifik bahwa variabel Current Ratio (X1) tidak berpengaruh parsial dalam memprediksi pertumbuhan laba pada Perusahaan Semen Indonesia yang terdaftar di Bursa Efek Indonesia. Seperti yang ditunjukkan Current Ratio (X1) memiliki nilai signifikansi

Hal ini sejalan jika dibandingkan dengan hasil penelitian Astuti (2014) menunjukkan bahwa secara simultan Current Ratio, Debt to Equity Ratio, Total Asset Turnover, Inventory Turnover, dan Return on Equity berpengaruh negatif dan tidak signifikan terhadap pertumbuhan laba. Berdasarkan hasil penelitian yang telah diuraikan sebelumnya bahwa variabel Total Assets Turnover (TAT) berpengaruh parsial dalam memprediksi pertumbuhan laba pada perusahaan industri dasar dan kimia yang terdaftar di Bursa Efek Indonesia.

Berdasarkan hasil penelitian yang telah diuraikan bahwa variabel Gross Profit Margin (GPM) berpengaruh parsial dalam memprediksi pertumbuhan laba pada perusahaan industri dasar dan kimia yang terdaftar di Bursa Efek Indonesia. 
Return on Equity (ROE) berpengaruh parsial dalam memprediksi pertumbuhan laba pada perusahaan industri dasar dan kimia yang terdaftar di Bursa Efek Indonesia. Pengaruh Current Ratio, Debt to Equity Ratio, Total Asset Turnover, Gross Profit Margin, dan Return on Equity terhadap Pertumbuhan Laba

\section{SIMPULAN}

Current Ratio tidak berpengaruh parsial dalam memprediksi pertumbuhan laba pada perusahaan industri dasar dan kimia yang terdaftar di Bursa Efek Indonesia. Total Assets Turnover berpengaruh parsial dalam memprediksi pertumbuhan laba pada perusahaan industri dasar dan kimia yang terdaftar di Bursa Efek Indonesia. Gross Profit Margin berpengaruh parsial dalam memprediksi pertumbuhan laba pada perusahaan industri dasar dan kimia yang terdaftar di Bursa Efek Indonesia. Return on Equity berpengaruh parsial dalam memprediksi pertumbuhan laba pada perusahaan industri dasar dan kimia yang terdaftar di Bursa Efek Indonesia. Current Ratio, Total Assets Turnover, Gross Profit Margin, dan Return on Equity berpengaruh simultan dalam memprediksi pertumbuhan laba pada perusahaan industri dasar dan kimia yang terdaftar di Bursa Efek Indonesia.

\section{UCAPAN TERIMAKASIH}

Ucapan terima kasih kepada Universitas Pembangunan Panca Budi dan Universitas Medan Area, yang mana telah memberikan fasilitas untuk mengabdi sebagai dosen.

\section{DAFTAR PUSTAKA}

Andari, M.R. (2015 ). Pengaruh NPL (Non Performing Loan) dan LDR (Loan to Deposite Ratio) terhadap Profitabilitas pada Perusahaan Perbankan yang Terdaftar di Bursa Efek Indonesia (BEI), Skripsi, Fakultas Ekonomi dan Bisnis, Universitas Pembangunan Panca Budi, Medan.

Arnita, V. (2019). Investment In Fixed Assets Listed In Indonesia Stock Exchange. Accounting and Business Journal, 1(1), 85-94.

Arnita, V., \& Aulia, A. (2020). Prekdisi Pertumbuhan Laba Dalam Rasio Keuangan Pada PT JAPFA COMFEED TBK. Jurnal Akuntansi Bisnis Dan Publik, 11(1), 115-122.

Astuti, N.I. (2014). Analisis Rasio Keuangan dalam Memprediksi Pertumbuhan Laba pada Perusahaan Telekomunikasi yang Terdaftar di Bursa Efek Indonesia (2011-2013), Skripsi, Fakultas Ekonomi dan Bisnis, Universitas Muhammadiyah Surakarta, Surakarta.

Atmaja, L.S. (2008). Teori dan Praktik Manajemen Keuangan. Yogyakarta : Andi.

Ghozali, I. (2011). Aplikasi Analisis Multivariate Dengan Program SPSS. Semarang : Badan penerbit Universitas Diponegoro

Giri, E.F. (2017). Akuntansi Menengah 1. Yogyakarta : UPP STIM YKPN.

Harahap, S.S. (2012). Teori Akuntansi, Cetakan Kedua Belas. Jakarta : PT Rajagrafindo Persada.

Hutauruk, M.R. (2019). Akuntansi Entitas Manufaktur. Yogyakarta : UPP STIM YKPN.

Nakhe, H.R.U. (2017). Analisis Pengaruh Operating Income Total Liabilities (OITL), Total Asset Turn Over (TATO), Net Profit Margin (NPM), dan Gross Profit Margin (GPM) terhadap Pertumbuhan Laba pada PT Matahari Putra Prima, Tbk, Skripsi, Fakultas Ekonomi dan Bisnis, Universitas Pembangunan Panca Budi, Medan.

Pedoman Penulisan Karya Ilmiah, 2014, Fakultas Ekonomi, Universitas Pembangunan Panca Budi, Medan.

Permatasari, I. (2016). Analisis Pengaruh Kinerja Keuangan Terhadap Pertumbuhan Laba (Studi Empiris Pada Perusahaan Manufaktur Sektor Industri Barang Konsumsi yang Terdaftar di Bursa Efek Indonesia Periode 2009-2014), Skripsi, Fakultas Ekonomi dan Bisnis, Universitas Negeri Lampung, Bandar Lampung.

Pulungan, A.A. (2010). Pengaruh Rasio Keuangan Terhadap Perubahan Laba pada Perusahaan Real Estate dan Property yang Terdaftar di Bursa Efek Indonesia, Skripsi, Fakultas Ekonomi Sumatera Utara, Medan.

Rudianto. (2012). Pengantar Akuntansi. Jakarta : Erlangga.

Samryn (2017). Pengantar Akuntansi, Cetakan Kelima. Depok : PT Rajagrafindo Persada.

Sibagariang, G.C. (2016). Pengaruh Likuiditas dan Profitabilitas Terhadap Pertumbuhan Laba pada Perusahaan Manufaktur Makanan dan Minuman yang Terdaftar di BEI, Skripsi, Fakultas Ekonomi dan Bisnis, Universitas Pembangunan Panca Budi, Medan.

Subramanyam, K.R. (2014). Analisis Laporan Keuangan. Jakarta : Salemba Empat. 
Sugiyono. (2011). Metode Penelitian Kuantitatif, Kualitatif Dan R\&D. Bandung : Alfabeta

Sugiyono. (2014). Metode Penelitian Pendidikan Pendekatan Kuantitatif, Kualitatif Dan R\&D. Bandung : Alfabeta

Sugiyono. (2017). Metode Penelitian Pendidikan Pendekatan Kuantitatif, Kualitatif Dan R\&D. Bandung : Alfabeta, CV.

Sujarweni. (2017). Analisis Laporan Keuangan. Yogyakarta : Pustaka Baru Press.

Suwardjono (2010). Teori Akuntansi : Pengungkapan dan Sarana Interpretatif, Edisi Ketiga, BPFE, Yogyakarta.

Tanzeh, A. (2011). Metodologi Penelitian Praktis. Yogyakarta : Teras

Trihastuti, S.A.Y. (2008). Analisis Rasio Keuangan Untuk Memprediksi Pertumbuhan Laba pada Perusahaan Properti yang Listing di BEI, Skripsi, Fakultas Ekonomi, Universitas Santa Dharma, Yogyakarta. https://www.idnfinancials.com 